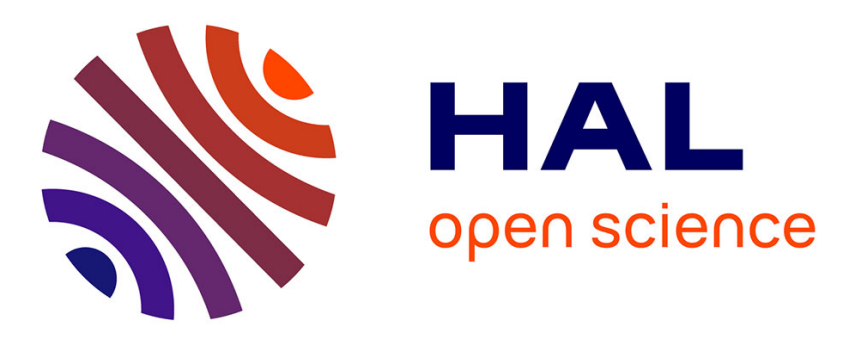

\title{
Computational Fluid Dynamics (CFD) Study on a Hybrid Airship Design
}

Jafirdaus Jalasabri, Fairuz Izzuddin Romli

\section{To cite this version:}

Jafirdaus Jalasabri, Fairuz Izzuddin Romli. Computational Fluid Dynamics (CFD) Study on a Hybrid Airship Design. International Review of Mechanical Engineering (I.RE.M.E.), 2017, 11 (8), pp.573. 10.15866/ireme.v11i8.11645 . hal-03349097

\section{HAL Id: hal-03349097 https://hal-univ-rennes1.archives-ouvertes.fr/hal-03349097}

Submitted on 20 Sep 2021

HAL is a multi-disciplinary open access archive for the deposit and dissemination of scientific research documents, whether they are published or not. The documents may come from teaching and research institutions in France or abroad, or from public or private research centers.
L'archive ouverte pluridisciplinaire HAL, est destinée au dépôt et à la diffusion de documents scientifiques de niveau recherche, publiés ou non, émanant des établissements d'enseignement et de recherche français ou étrangers, des laboratoires publics ou privés. 


\title{
Computational Fluid Dynamics (CFD) Study on a Hybrid Airship Design
}

\author{
Jafirdaus Jalasabri, Fairuz I. Romli
}

\begin{abstract}
The aerodynamic lift and drag performance is one of the important considerations for hybrid airship configuration design. In conjunction with this, simulation study of aerodynamic characteristics can certainly benefit the process of deriving the best possible configuration for hybrid airship design. The aim of this study is to investigate the trend of aerodynamic lift and drag performance for an airship design in different velocities, altitudes and design fineness ratio using the Star CCM+ analysis tool. The airship model applied in this case study is an approximate model of the Atlant-100 airship. It is found that the airship model with low design fineness ratio typically generates much better aerodynamic lifting force in comparison to those with high design fineness ratio. On the other hand, while the range of estimated drag coefficient values is found to be rather insignificantly different, the presence of effects from the design fineness ratio is still evident. Generally, high design fineness ratio for the airship model seems to produce much lower drag force. Copyright (C) 2017 Praise Worthy Prize S.r.l. - All rights reserved.
\end{abstract}

Keywords: Hybrid Airship, Aerodynamic Performance, Atlant-100, Star CCM+, CFD Analysis

\section{Introduction}

Airship is a type of lighter-than-air (LTA) aircraft that uses gas of lower density than air like helium or hydrogen to produce its lift. This is different from a fixed or rotary wing aircraft, which primarily generates their lift from the wing structure.

The development history of airships can be traced back to 1784 with the first recorded flight of a non-rigid dirigible by Jean-Pierre Blanchard. Back then, the airships were touted to become the main means of air transportation for passengers and cargo. However, series of unfortunate fatal accidents that occurred during their operation caused huge negative impact to their usage and development.

Of particular note, the accident on 6th May 1937 involving German rigid airship LZ 129 Hindenburg has essentially marked the end of commercial airship era [1].

Eventually, winged aircraft have replaced them as the primary transport means in passengers air transportation industry and airships are relegated for mostly tourism or advertising purposes up to these days.

Recently, there have been many talks to revive the use of airships for mass passengers air transportation. This is primarily due to some advantages of the airship operation that can be beneficial to solve ongoing issues with current winged aircraft operation. This has been highlighted by a few studies that compare airship's operation against other types of commercial transportation means [2], [3].

In brief, airship's operation is less noisy and more cost-effective in terms of fuel consumption [4].
As for the latter argument, it is stated that half of the fuel in conventional aircraft is used to keep it airborne while the use of aerostatic lift on hybrid airship can potentially reduce the amount of fuel use to generate the required lifting force [5]. Thus airship is a more environmental-friendly option for air transport [6].

Moreover, safety of airship operation that used to be a major concern in the past has been improved, especially through use of helium gas instead of highly combustible hydrogen gas. The operational efficiency of airships is also improved by introduction of hybrid airship designs.

For this type of airship design, about $60 \%$ to $80 \%$ of its lift comes from lifting gases while the remaining comes from aerodynamic shape of the airship [5].

Additionally, the total lift for hybrid airships can be further increased through vectored thrust element [7]. In other words, the hybrid-type airship design combines LTA technology of aerostats and heavier-than-air (HTA) technology of the traditional fixed or rotary wing aircraft, which offers few advantages over the traditional airship configuration. For instance, by adding wings to the main vehicle body, it can produce a higher aerodynamic lift, reduce drag, improve vehicle stability and increase payload capability. Having said that, it is imperative for hybrid airship to be designed with good aerodynamic shape and equipped with a proper thrust capability.

Unlike the conceptual development process of winged aircraft that has been made effectively easier using wellestablished empirical relationships between their design parameters and their operational flight performance, the same cannot be said about airship. There is generally lack of parametric studies done on hybrid airship design that address performance tradeoffs due to effects of its design 
variables. Hence the primary objective of this study is to investigate the possible effect of the design fineness ratio towards the aerodynamic performance of a hybrid airship (lift and drag coefficients) with varying cruise velocities and altitudes using computational fluid dynamics (CFD) software. Such information will be greatly useful during conceptual design phase where many of the early design decisions are being made.

\section{Simulation Setup}

CFD simulation is a well-accepted alternative practice to conducting actual experiment in studying aerodynamic characteristics of a body. In aerospace field, this includes simulation of flows around airfoils such as in Ref. [8], [9], [16]-[19]. For this study, the focus is placed on airships for possible future commercial mass passengers transportation. There are several existing or underdevelopment airship designs that can be used for transporting passengers. The chosen reference design for this study is the Atlant-100 airship. This hybrid airship could carry up to 200 passengers and uses helium gas as lifting gas, with total envelope volume of $100,000 \mathrm{~m}^{3}$ [10], [11]. It is also equipped with the active ballasting system concept, which has been anticipated to offer an additional capability to reduce fuel consumption and improve the control of pitching and baloney volume variation [11]. Furthermore, it is capable of vertical takeoff and landing (VTOL), and short take-off and landing (STOL) from unprepared site or surface, which enables it to pick and drop passengers almost anywhere.

An approximate design model of Atlant-100 has been developed in CATIA for this CFD simulation study. The model is illustrated in Fig. 1. It should be noted that the model is constructed with estimated dimensions based on the available design information of Atlant-100 airship in public domain and no actual design data is obtained from the manufacturer. Star CCM+ software is applied for the CFD analysis, with the Spalart-Allmaras (S-A) turbulence model and the polyhedral cells meshing setup. The model meshing illustration and details information are shown in Fig. 2 and Table I, respectively. Meanwhile, more details regarding S-A are available in Ref. [12].

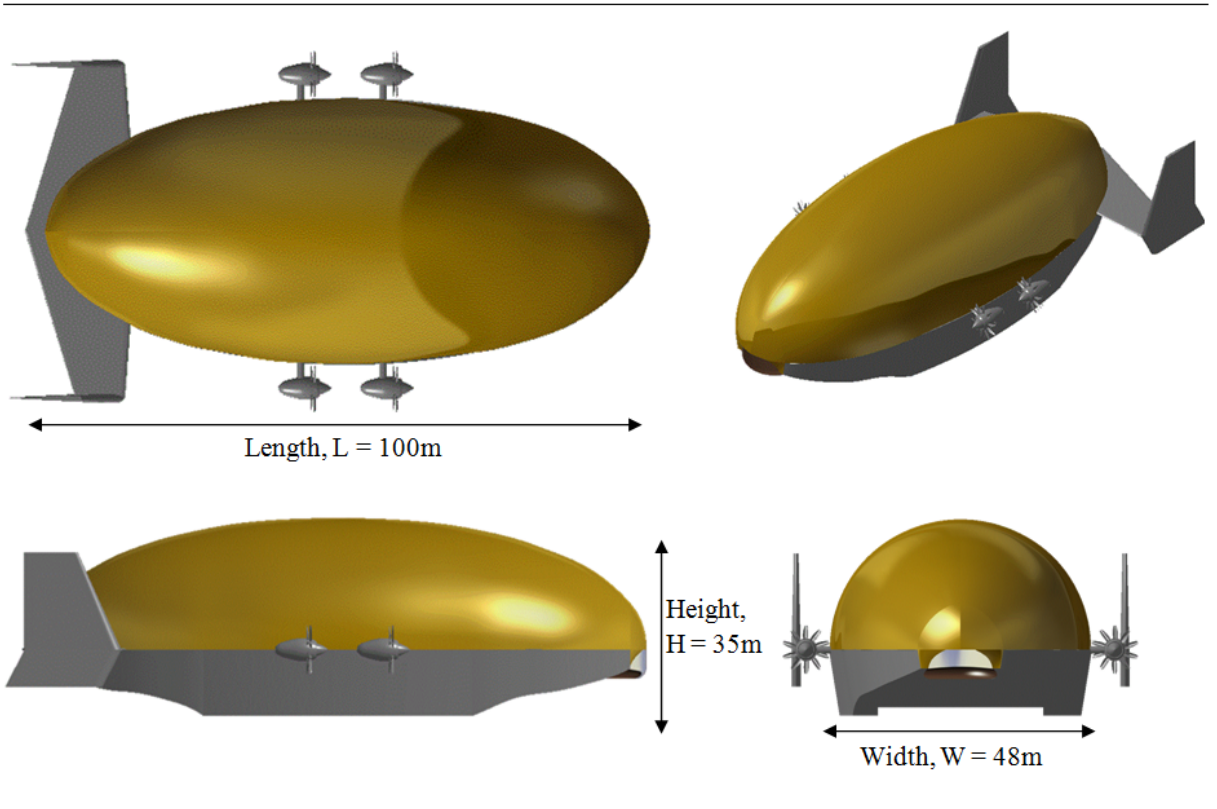

Fig. 1. Simulation Model of Approximate Atlant-100 Airship Design

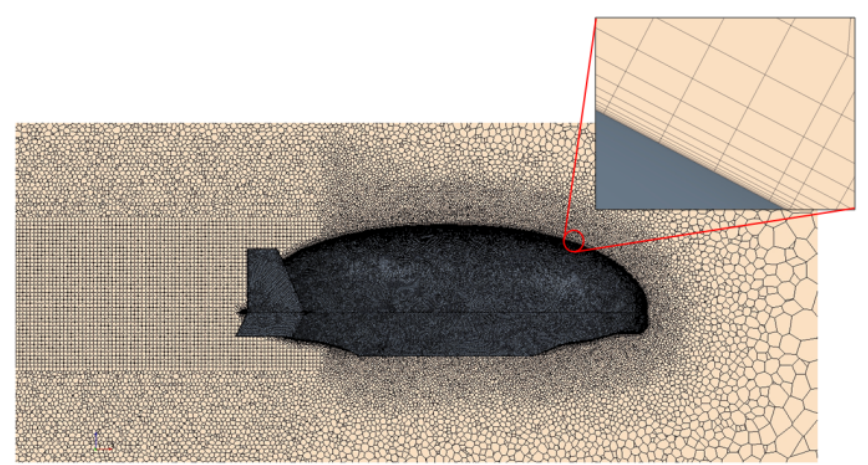

Fig. 2. Polyhedral Cells Meshing with 12 Boundary Layers 
TABLE I

MESH CONTINUA MODELLING

\begin{tabular}{cc}
\hline \hline Mesh Model & Polyhedral Mesher \\
Base size & $3.2 \mathrm{~m}$ \\
No. Prism Layer & 12 \\
Prism layer thickness & $33.33 \%$ (Default) \\
Growth rate & 1.3 (Default) \\
Y-values & All + y wall treatments \\
& (Default) \\
Surface Size (Target) & $1.6 \mathrm{~m}$ \\
Tunnel Surface Size & $204.8 \mathrm{~m}$ \\
No. of Cells & $\sim 6$ millions \\
\hline \hline
\end{tabular}

The simulation has been executed for several different operating conditions to establish the underlying trend of the airship's aerodynamic performance for a given design fineness ratio with varying values of velocity and altitude.

The settings for the value of cruise velocity are 100 $\mathrm{km} / \mathrm{h}, 140 \mathrm{~km} / \mathrm{h}$ and $190 \mathrm{~km} / \mathrm{h}$ while those for altitude are $1500 \mathrm{~m}, 2000 \mathrm{~m}$ and $2500 \mathrm{~m}$. These velocities and altitudes are set with reference to the published engineering data of the Atlant-100 airship as tabulated in Table II.

The range of values chosen can be observed to be above and below the specification in Table II. This has been intentionally done to study the performance of the airship within operational envelope that is of high interest for commercial transport purposes in this study.

The simulation runs at different altitudes will have different boundary conditions and air properties as shown in Table III.

The simulation environment must be made adequately large enough to avoid any effects of numerical external condition to the flow around the airship model [13].

Fig. 3 shows the constructed simulation environment for this study.

Moreover, to study the effects of different design fineness ratios, the constructed Atlant-100 airship model is scaled according to three selected fineness ratio values.

This design fineness ratio, which is defined as a ratio of the airship's length to its width, is varied from the original design's 0.93 to 1.39 and 2.08 .

TABLE II

AIRSHIP SPECIFICATION BENCHMARKING [11], [12]

\begin{tabular}{|c|c|}
\hline Engineering Data & Atlant-100 \\
\hline Mission & Commercial / Cargo \\
\hline Origin & Russia \\
\hline Vertical Take-Off and Landing (VTOL) & Yes \\
\hline Short Take-Off and Landing (STOL) & Yes \\
\hline Envelope Volume, & $100,000 \mathrm{~m}^{3}$ \\
\hline Passenger (person) & 200 (Max) \\
\hline Classifications & Hybrid airships \\
\hline Lifting Gases Types & Helium \\
\hline Airship length, m & $100 \mathrm{~m}$ \\
\hline Airship width, m & $48 \mathrm{~m}$ \\
\hline Airship height, m & $35 \mathrm{~m}$ \\
\hline \multirow[t]{3}{*}{ Airship Take-off weight, tons } & $(97,000 \mathrm{~kg})$ \\
\hline & 97 tons \\
\hline & 60 tons (payload) \\
\hline Cruise speed & $75 \mathrm{kts}(140 \mathrm{~km} / \mathrm{h})$ \\
\hline Max. Speed & 108 kts $(200 \mathrm{~km} / \mathrm{h})$ \\
\hline Max. Altitude & $1,500 \mathrm{~m}$ \\
\hline
\end{tabular}

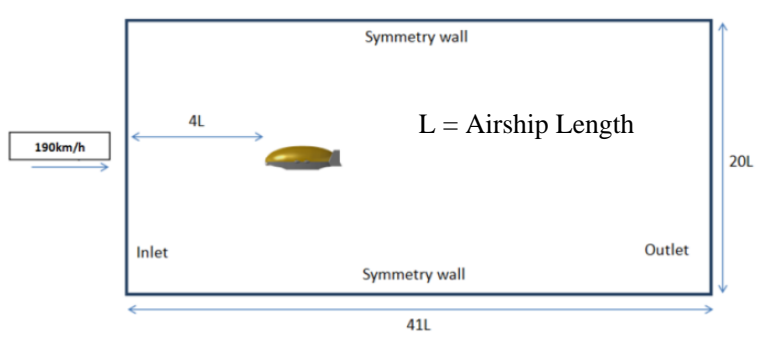

Fig. 3. Setting of the Simulation Environment

\section{Results and Discussion}

In total, 28 simulation cases have been executed in the study for different combinations of velocity, altitude and design fineness ratio. The obtained simulation results for lift and drag coefficients $\left(C_{L}\right.$ and $C_{D}$, respectively) are as tabulated in Table IV. The following discussion is made by observing the resultant data trend.

\section{III.1. Effect of Fineness Ratio with Altitude}

Fig. 4 shows CFD simulation results of lift coefficient for different design fineness ratios at different altitudes.
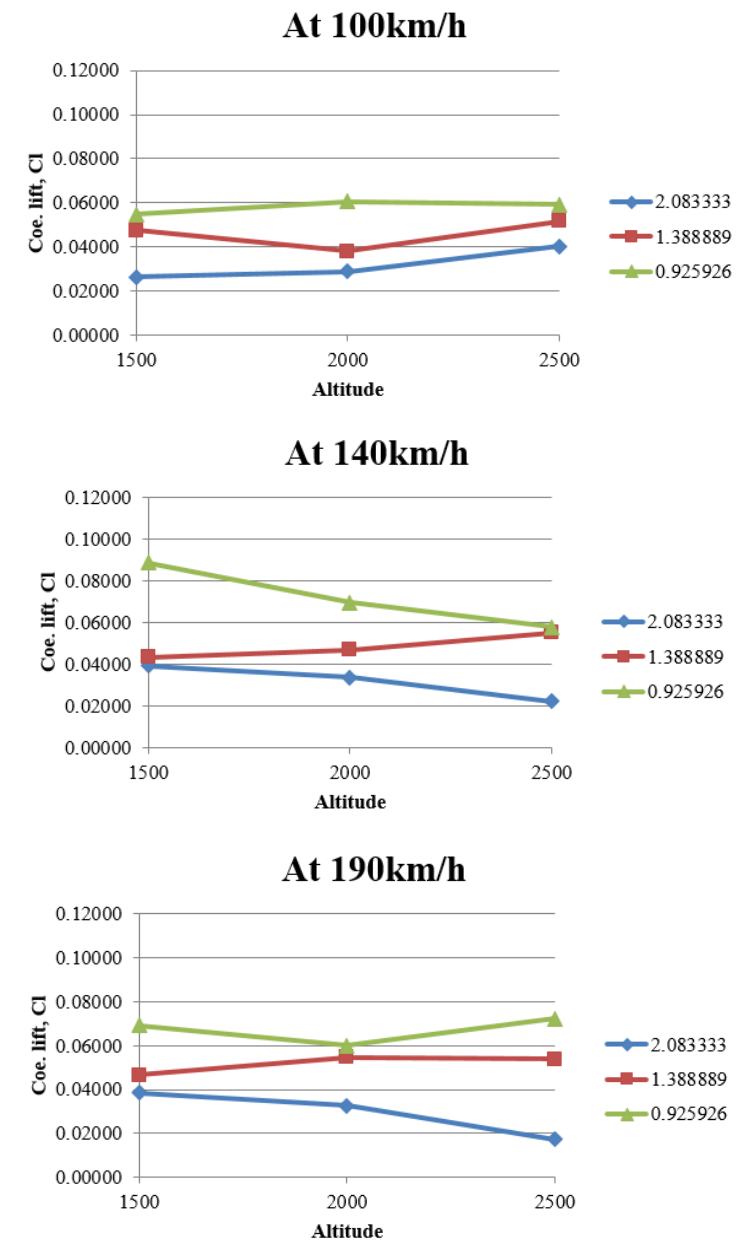

Fig. 4. Lift Coefficient at Different Cruise Altitudes 
As observed from the simulation, the major components that will affect the generation of lift force for the airship model are its hull and wing, which may dictate whether the lift generated is positive or negative.

Based on Fig. 4, airship with high design fineness ratio appears to produce lower aerodynamic lift for all speeds at any of the three altitudes studied in the analysis.

This is because, at small design fineness ratio, the size of the airship's wing is also small and this subsequently results in less disturbance for the aerodynamic lift produced from hull body, leading to much better aerodynamic lift force generation.

However, resultant trend of the generated aerodynamic lift coefficient can be seen to be inconsistent between the different design fineness ratios.

For instance, for design fineness ratio of 2.08 at cruise velocity of $190 \mathrm{~km} / \mathrm{h}$, the generated aerodynamic lift continues to be reduced as the altitude is increased.

Meanwhile, for design fineness ratio of 0.93 , the generated lift is reduced when the altitude is increased at first, but then it is increased at even higher altitude.

TABLE III

ANALYSIS ENVIRONMENT AND BOUNDARY CONDITIONS

\begin{tabular}{cccccc}
\hline \hline $\begin{array}{c}\text { Altitude } \\
(\mathrm{m})\end{array}$ & $\begin{array}{c}\text { Air } \\
\text { Density } \\
\left(\mathrm{kgm}^{-3}\right)\end{array}$ & $\begin{array}{c}\text { Viscosity } \\
(\mathrm{Pa}-\mathrm{s})\end{array}$ & $\begin{array}{c}\text { Temperature } \\
(\mathrm{K})\end{array}$ & $\begin{array}{c}\text { Pressure } \\
(\mathrm{Pa})\end{array}$ & $\begin{array}{c}\text { Speed of } \\
\text { Sound }\left(\mathrm{ms}^{-1}\right)\end{array}$ \\
\hline 1500 & 1.0501 & $1.76 \mathrm{E}-05$ & 278.4 & 84555.7 & 334.5 \\
2000 & 1.0065 & $1.75 \mathrm{E}-05$ & 275.2 & 79495.2 & 332.5 \\
2500 & 0.9164 & $1.73 \mathrm{E}-05$ & 272.0 & 74681.9 & 330.6 \\
\hline \hline
\end{tabular}

TABLE IV

Results For SimUlation CASE STUdies

\begin{tabular}{|c|c|c|c|c|}
\hline $\begin{array}{c}\text { Fineness } \\
\text { Ratio }\end{array}$ & $\begin{array}{c}\text { Altitude } \\
(\mathrm{m})\end{array}$ & 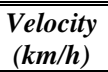 & $C_{L}$ & $C_{D}$ \\
\hline \multirow{9}{*}{2.08} & \multirow{3}{*}{1500} & 100 & 0.0263 & 0.0245 \\
\hline & & 140 & 0.0393 & 0.0262 \\
\hline & & 190 & 0.0386 & 0.0273 \\
\hline & \multirow{3}{*}{2000} & 100 & 0.0288 & 0.0260 \\
\hline & & 140 & 0.0338 & 0.0243 \\
\hline & & 190 & 0.0326 & 0.0260 \\
\hline & \multirow{3}{*}{2500} & 100 & 0.0404 & 0.0267 \\
\hline & & 140 & 0.0223 & 0.0247 \\
\hline & & 190 & 0.0173 & 0.0226 \\
\hline \multirow{9}{*}{1.39} & \multirow{3}{*}{1500} & 100 & 0.0475 & 0.0358 \\
\hline & & 140 & 0.0436 & 0.0319 \\
\hline & & 190 & 0.0466 & 0.0331 \\
\hline & \multirow{3}{*}{2000} & 100 & 0.0381 & 0.0362 \\
\hline & & 140 & 0.0469 & 0.0337 \\
\hline & & 190 & 0.0548 & 0.0343 \\
\hline & \multirow{3}{*}{2500} & 100 & 0.0517 & 0.0360 \\
\hline & & 140 & 0.0552 & 0.0356 \\
\hline & & 190 & 0.0539 & 0.0357 \\
\hline \multirow{9}{*}{0.93} & \multirow{3}{*}{1500} & 100 & 0.0547 & 0.0329 \\
\hline & & 140 & 0.0889 & 0.0373 \\
\hline & & 190 & 0.0692 & 0.0334 \\
\hline & \multirow{3}{*}{2000} & 100 & 0.0607 & 0.0328 \\
\hline & & 140 & 0.0696 & 0.0351 \\
\hline & & 190 & 0.0599 & 0.0321 \\
\hline & \multirow{3}{*}{2500} & 100 & 0.0591 & 0.0325 \\
\hline & & 140 & 0.0579 & 0.0323 \\
\hline & & 190 & 0.0724 & 0.0346 \\
\hline
\end{tabular}

It is hard to exactly pinpoint on the exact cause of this situation by just looking at the simulation results.
There are several factors that influence these inconsistent results for the airship's aerodynamic lift coefficient and one of them is probably the inability of Spalart-Allmaras turbulence model to capture much details on shear forces.

It should be noted that shear forces can have up to $90 \%$ contribution towards lift coefficient value.

Furthermore, at low altitude, the trend of the produced lift coefficient seems to be less consistent in comparison to that at high altitude. This can be contributed to the weakening of the environmental pressure and shear force around the body as altitude is increased [12], which allows easier task for the simulation to capture the lift coefficient energy.

Last but not least, this result for aerodynamic lift coefficient is heavily influenced by the shape of approximate Atlant-100 airship model and by how the scaling process for the different design fineness ratio is done.

On the other hand, application of the Spalart-Allmaras turbulence model has resulted in an essentially constant trend for the drag coefficient. From the simulation results of drag coefficient as shown in Fig. 5, it can be deduced that design fineness ratio of 1.39 seems to produce higher aerodynamic drag coefficient compared to others.
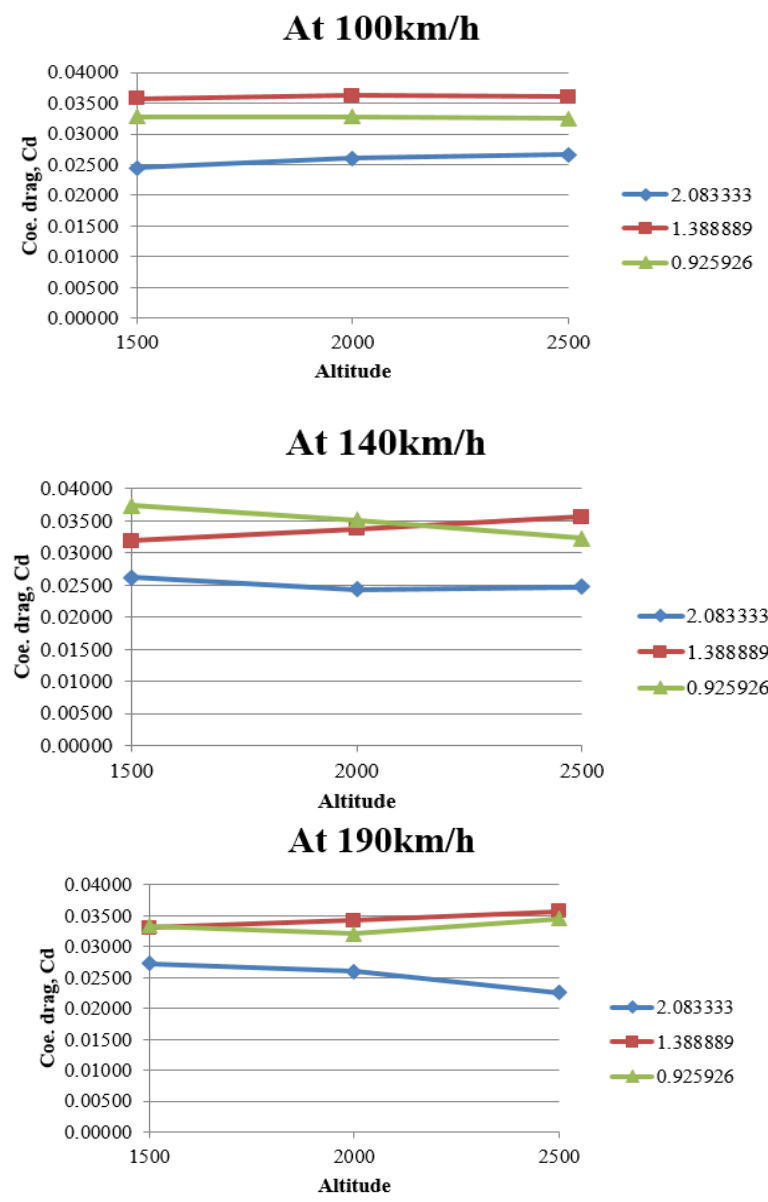

Fig. 5. Drag Coefficient at Different Cruise Altitude 
As can be observed during the simulation, at the design fineness ratio of 1.39 , the aerodynamic drag of the airship model is high due to more downward airflow.

This condition is contributed to its smaller wing size. It should be noted that the resultant aerodynamic drag coefficient is heavily influenced by the shape of the Atlant-100 airship design and by how the model scaling up process is done, which is illustrated in Fig. 6. More positive drag from the wing is generally produced with decreasing altitude.

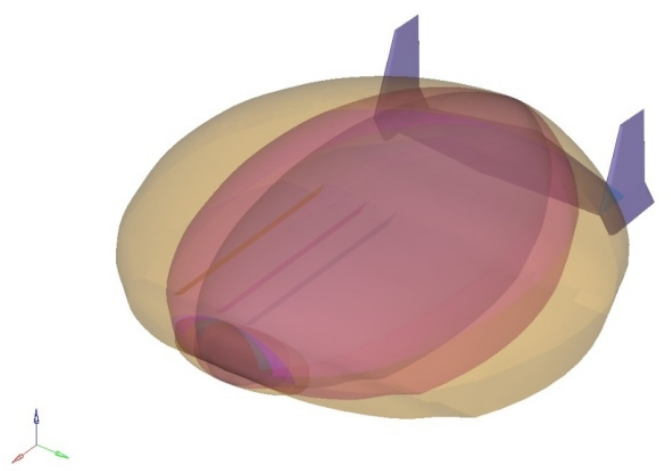

Fig. 6. Design Scaling for Different Fineness Ratios

All in all, based on the inconsistent trend of the results, it is believed that the effect of altitude to the generation of the aerodynamic forces is not as straightforward. The difference in the trend highlights a significant impact of design fineness ratio and its influence has to be taken into account when the airship is conceptually designed.

\section{III.2. Effect of Fineness Ratio with Velocity}

In this section, the results are represented in terms of plots of the aerodynamic coefficients against the chosen cruise velocities. This is done to highlight the effects of the latter. In Fig. 7, it can be observed that the trend of lift force produced with variation of the cruise velocity is rather unsteady. Nevertheless, it is also observed that the lift coefficient for the high fineness ratio airship model is consistently lower than that for the lower ones at all of the simulated altitudes. On the other hand, results of drag coefficient in Fig. 8 highlight that the magnitude is essentially constant within a certain boundary of values when the cruise velocity is increased for all cases of different altitudes. Based on this observation, it can be said that the combination impact of fineness ratio and cruise velocity on the generated drag force on the airship is rather small. This notion is shared by the study presented in Ref. [14], which states that the variation of the drag coefficient is rather insignificant and can be considered as constant when the Mach number is less than 0.7. This is due to negligible compressible and wave drag effects around the body. Furthermore, results from another study on a hybrid airship in Ref. [15] shows that the impact of the velocity on drag coefficient is more pronounced at very low altitudes close to the sea level.

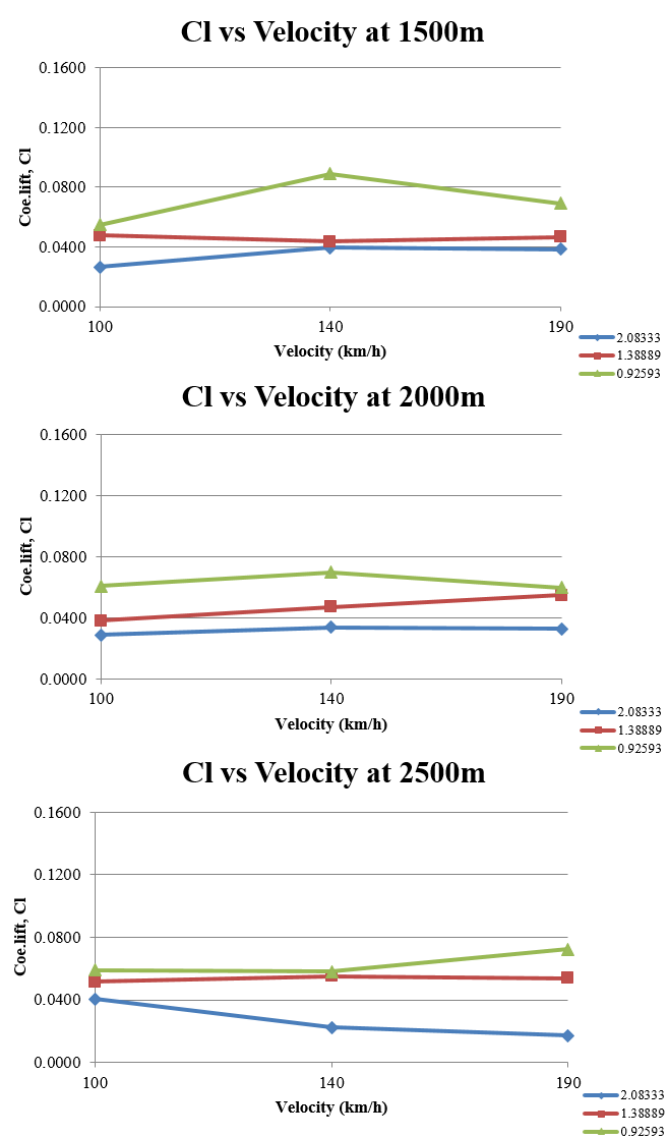

Fig. 7. Lift Coefficient at Different Cruise Velocities

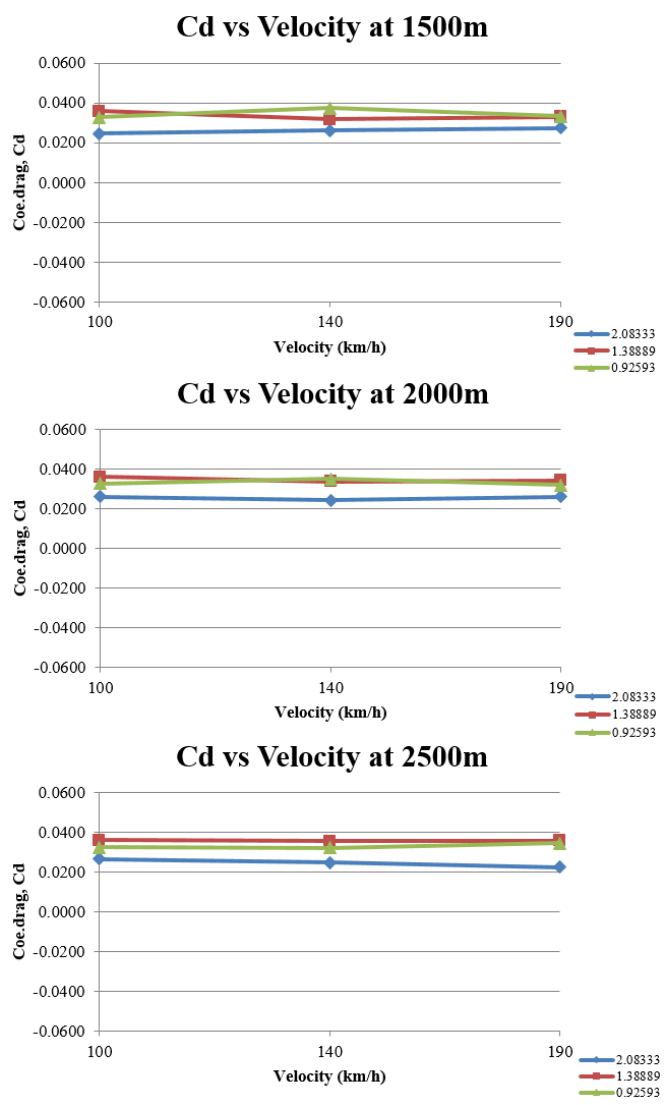

Fig. 8. Drag Coefficient at Different Cruise Velocities 
Since all simulation cases in this study take place at the altitudes higher than $1500 \mathrm{~m}$ above the sea level altitude, it is therefore should be expected that the velocity impact on the drag coefficient is low based on this finding.

It is clearly seen that there is no obvious trend that can be derived from the results on the relationship between the aerodynamic coefficients and the design fineness ratio with varying cruise velocity. This once again highlights the presence of effects of the design fineness ratio, which should be considered together with the cruise velocity to predict aerodynamic performance of the airship design.

\section{Conclusion}

This research aims to study the effects of fineness ratio on aerodynamic performance of a hybrid airship design. To achieve this, CFD simulation analysis is performed using the Star CCM+ software. An approximate model of the Atlant-100 airship is taken as the reference design and constructed for the case studies.

The simulation analysis is carried out with the SpalartAllmaras turbulence model and polyhedral cells meshing.

The resultant simulation data trend and pattern of both lift and drag coefficients are compared with theories and previous hybrid airship simulation cases. From obtained results of the aerodynamic lift coefficient, the simulation shows an unsteady flow pattern for all sizes of the airship model studied. It is believed that the underlying trend for the lift coefficient is hard to capture due to the inability of the Spalart-Allmaras turbulence model to capture much details on the shear forces.

In the meantime, the obtained results for the aerodynamic drag coefficient show that its value is essentially constant for every value of velocity and altitude studied here. This pattern is consistent with several other published studies before. The aerodynamic drag coefficient is higher for airship design fineness ratio of 1.39 due to its wing configuration. Plus, it should be noted that these aerodynamic performance results are also heavily influenced by the shape of the Atlant-100 airship and how the constructed airship model is scaled up for different design fineness ratios.

On the whole, it is concluded based on the simulation results that the estimated Atlant-100 airship model with small fineness ratio of 0.93 will produce a better lifting force. This can be as higher as $8 \%$ to $12 \%$ in comparison to that for the larger ones.

Although the effect on the drag coefficient is quite small, higher design fineness ratio for the airship model seems to produce a much lower drag. This should be rather expected due to the slenderness of its overall shape.

Nevertheless, it is hard to establish any apparent relationship for the aerodynamic performance of the airship due to the inconsistent trend of the results. This also indirectly infers that the considered parameters are not independent to each other for their effects on the resultant aerodynamic forces on the airship. Further study should also include the validation of the simulation result through experimental means.

\section{References}

[1] H. Braun, "Lighter-than-air v. Heavier-than-air: How can Network Effects Explain the Failure of Airship Technology?" The Journal of European Economic History, vol. 38, no. 2, 2009.

[2] A. W. Schafer and I. A. Waltz, "Air transportation and the environment," Transport Policy, vol. 34, pp. 1-4, 2014.

[3] N. O. Aminian and F. I. Romli, "Study on the Potential of Airships as Urban Mass Public Transport in Malaysia", Journal of Mechanical Engineering, 2017.

[4] A. Cimarelli, M. Madonia, D. Angeli, A. Dumas, "Aerodynamic Study of Advanced Airship Shapes," Journal of Aerospace Engineering, vol. 30, no. 3, 2017.

[5] B. E. Prentice and R. Knotts, "Cargo Airships: International Competition," Journal of Transportation Technologies, vol. 4, pp. 187-195, 2014.

[6] B. E. Prentice, J. Ashcroft and r. Hochstetler, "Can Modern Transport Airships Change the World?" 18th AIAA Lighter-ThanAir Systems Technology Conference, Seattle, Washington, USA, 4 - 7 May 2009.

[7] L. Zhang, M. Lv, J. Meng, H. Du, "Conceptual Design and Analysis of Hybrid Airships with Renewable Energy," Proc. IMechE Part G: Journal of Aerospace Engineering, 2017.

[8] Tebbal, A., Saidi, F., Noureddine, B., Imine, B., Hamoudi, B., Numerical Study of the Roughness Influence on NACA 63-430 Profile Aerodynamic Performance, (2016) International Review of Mechanical Engineering (IREME), 10 (4), pp. 231-238. doi:https://doi.org/10.15866/ireme.v10i4.8904.

[9] Saatchi, D., Fathali, M., Khojasteh, A., The Impacts of Five Different Turbulence Models on the Accuracy of Computational Aeroacoustic Results for an Airfoil and Acoustic Localization Analysis for Well Suited Model, (2014) International Review of Mechanical Engineering (IREME), 8 (2), pp. 387-398.

[10] F. X. Govers III, "Aeroscraft Begins Flight Testing Following FAA Certification", New Atlas, 9th September 2013, http://newatlas.com/ aeros-gets-faa-approval-for-testing/28970/ [Accessed: Oct 2015].

[11] Augur-RosAeroSystems,"ATLANT: The future technology for Northern Territories," 2009.

[12] V. Voloshina, Y. K. Chena and R. Calay, "A comparison of turbulence models in airship steady-state CFD simulations," Journal of Cornell University, pp. 2- 14, 2012.

[13] M. Battipede, P. Gili and M. Vazzola, "Structural and Aerodynamics Analysis on Different Architectures for Elettra Twin Flyer Prototype," Journal of Intelligent and Robotic Systems, vol. 72, no. 1, pp. 123-144, 2013.

[14] M. Sadraey, Aircraft Performance: Analysis. Saarbrücken, Germany: VDM Verlag Dr. Müller, 2009.

[15] A. Dumas, M. Trancossi, M. Madonia, J. Pascoa, G. Ilieva and A. Coppola, "CFD Analysis and Optimization of Variable Shape Airship," Proceedings of the ASME 2012 International Mechanical Engineering Congress \& Exposition, Houston, Texas, USA, November 9-15, 2012.

[16] Ahmed, S., Nazari, A., Wahba, E., Numerical Analysis of Separation Control Over an Airfoil Section, (2014) International Review of Aerospace Engineering (IREASE), 7 (2), pp. 61-68.

[17] Ahmed, S., Nazari, A., Numerical Study of Rotating Cylinder Effects on the Performance of a Symmetrical Airfoil Section, (2015) International Review on Modelling and Simulations (IREMOS), 8 (2), pp. 239-244.

[18] Aziz, M., Elsayed, A., CFD Investigations for UAV and MAV Low Speed Airfoils Characteristics, (2015) International Review of Aerospace Engineering (IREASE), 8 (3), pp. 95-100.

[19] Bekka, N., Bessaïh, R., Sellam, M., Numerical Study of Transonic Flows Using Various Turbulence Models, (2015) International Review of Aerospace Engineering (IREASE), 8 (6), pp. 216-224. 


\section{Authors' information}

Department of Aerospace Engineering,

Universiti Putra Malaysia,

Malaysia.

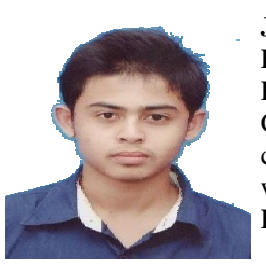

Jafirdaus Jalasabri received his Bachelor of Engineering (Aerospace) degree from Universiti Putra Malaysia in 2013. He currently works as a CAE/CFD Engineer at Proton Holdings company in Malaysia. He is also currently working on his Master's degree in Aerospace Engineering at Universiti Putra Malaysia.

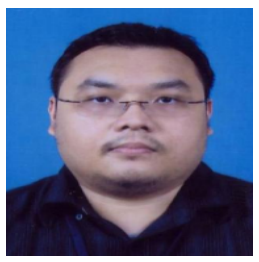

Fairuz I. Romli received his $\mathrm{PhD}$ degree in Aerospace Engineering from Georgia Institute of Technology, USA in 2009. He currently works as a Senior Lecturer in the Department of Aerospace Engineering, Universiti Putra Malaysia. His research interests include design methodologies and tools, optimization studies and also air traffic management. 